\title{
Suitability analysis of Lampung Bay waters for grouper Epinephelus sp. farming activities
}

\section{Analisis kesesuaian perairan Teluk Lampung untuk kegiatan budidaya ikan kerapu Epinephelus sp.}

\section{Herman Yulianto ${ }^{1}$, Agus Hartoko ${ }^{2}$, Sutrisno Anggoro ${ }^{3}$, Qadar Hasani ${ }^{1}$, Dwi Mulyasih ${ }^{4}$, Putu Cinthia Delis ${ }^{1 *}$}

\author{
${ }^{1}$ Department of Aquatic Resources, Agriculture Faculty, University of Lampung \\ ${ }^{2}$ Departement of Aquatic Resources Management, Agriculture Fisheries and Biology Faculty
} Bangka Belitung University

${ }^{3}$ Departement of Aquatic Resources Management, Fisheries and Marine Science Faculty, Diponegoro University

${ }^{4}$ Department of Aquaculture, Agriculture Faculty, University of Lampung

*Email: putu.delis@fp.unila.ac.id

\begin{abstract}
Grouper Epinephelus sp. farming activities in Lampung Bay is limited to an area of 77 hectares, while areas that are potential to be used for grouper farming are still very wide. Therefore, this study aimed to assess the suitability of Lampung Bay waters for grouper farming activities. The study was conducted in 20 stations with ecological preference considerations. The parameters observed were physicochemical (water depth, temperature, water transparency, the load of suspended solids, $\mathrm{pH}$, dissolved oxygen, salinity, nitrate, and phosphate) and biological parameters (phytoplankton abundance and chlorophyll-a concentration). After the data were completely obtained, the data were processed into suitability matrix resulting in scores that will be grouped into four classes, namely S1 (highly suitable), S2 (moderately suitable), S3 (marginally suitable), N (not suitable). The geostatistical model was used to perform the earth's surface mapping based on biotic and abiotic parameters that were analyzed. Based on the results of the analysis in this study, the conditions of Lampung Bay waters were suitable for grouper farming activities. Marine area that could be used for grouper farming was 33,847.12 hectares (S1: 15,712.6 ha, S2: 13,294.7 ha and S3: 4,209.82 ha) in the area around Puhawang Island, Kelagian Island, Maitem Island, Tegal Island to Hurun Bay.
\end{abstract}

Keywords: Lampung Bay, grouper, suitability analysis, fish farming

\begin{abstract}
ABSTRAK
Kegiatan budidaya ikan kerapu Epinephelus sp. di Teluk Lampung masih terbatas pada lahan seluas 77 hektar, sedangkan lahan yang berpotensi digunakan untuk budidaya ikan kerapu masih sangat luas. Oleh karena itu, penelitian ini bertujuan mengkaji kesesuaian perairan Teluk Lampung untuk kegiatan budidaya ikan kerapu. Penelitian dilakukan di 20 stasiun dengan pertimbangan ecological preference. Parameter yang diamati yaitu parameter fisika-kimia perairan (kedalaman, suhu, kecerahan, muatan padatan tersuspensi, pH, oksigen terlarut, salinitas, nitrat, dan fosfat) serta parameter biologi (kelimpahan fitoplankton dan konsentrasi klorofil-a). Setelah data parameter terpenuhi, data diolah ke dalam matriks kesesuaian sehingga menghasilkan skor yang akan dikelompokkan ke dalam empat kelas, yaitu S1 (highly suitable), S2 (moderately suitable), S3 (marginally suitable), $\mathrm{N}$ (not suitable). Model geostatistik digunakan untuk melakukan pemetaan permukaan bumi berdasarkan data parameter biotik dan abiotik yang dianalisis. Berdasarkan hasil analisis pada penelitian ini, kondisi perairan Teluk Lampung sesuai untuk kegiatan budidaya ikan kerapu. Luas perairan laut yang dapat digunakan untuk kegiatan budidya ikan kerapu yaitu, 33.847,12 hektar (S1: 15.712,6 ha, S2: 13.294,7 ha dan S3: 4.209,82 ha) di daerah sekitar Pulau Puhawang, Pulau Kelagian, Pulau Maitem, Pulau Tegal hingga Teluk Hurun.
\end{abstract}

Kata kunci: Teluk Lampung, ikan kerapu, analisis kesesuaian, budidaya 


\section{INTRODUCTION}

Grouper Epinephelus sp. is a commodity that has high economic value either in the tropical and subtropical areas (Pierre et al., 2007). Groupers widely spread in the Indo-Pacific waters, especially Southeast Asia and have been widely consumed globally (Pierre et al., 2008). Groupers from Ephinephelinae subfamily consist of 159 species and spread in the tropical and subtropical waters (Pieree et al., 2007; Harikrishnan et al., 2010). Groupers that have been currently cultivated are humpback grouper Cromileptes altivelis (Fauzi et al., 2008; Tridjoko et al., 2009), tiger grouper Epinephelus Fuscoguttatus (Ruslan \& Istikomah, 2009; Mariskha \& Abdulgani, 2012; Afero \& Safrita, 2015), leopard coral trout grouper Plectropomus leopardus (Aslianti, 2010), and king grouper Epinephelus lanceolatus (Imanto \& Suastika, 2007).

In Indonesia, groupers that have been commercially cultivated are humpback grouper, leopard coral trout grouper, and dusky tail grouper Epinephelus bleekeri (Pramono et al., 2005; Tridjoko et al., 2009; Aslianti, 2010). Based on one-year performance report of the Ministry of Maritime Affairs and Fisheries (2015), grouper fish production in 2013 was as much as 113,368 tons consisting of 13,464 tons from fish farming and 99,904 tons from fishing with Hong Kong as the biggest export destination country, contributing $90 \%$ of total production. Groupers are usually exported in raw form (Luhur \& Tajerin, 2016). From these data, it can be seen that most of the groupers exported from Indonesia are from grouper catching in natural waters.

Indonesia is known as a country with the highest production of grouper by catching compared to China, Mexico, Pakistan, and Malaysia (Pierre et al., 2008). In Weh Island, Sabang, grouper is still the highest catching commodity with an average number of $1.13 \mathrm{~kg} /$ trip (Hastuty et al., 2014). Similarly, Barru waters, South Sulawesi, groupers are also the dominant catching commodity beside red snapper Lutjanus malabaricus (Sumiono et al., 2010). When grouper is caught constantly, it is feared that the balance of the stock in nature will be disrupted. Nuraini (2007) reported in Berau waters, East Kalimantan, it was known that from 25 grouper species that were analyzed, five species were run into decreasing population. Even today the humpback grouper already on the CITES list because the population in nature is starting to decline (Wardana \& Tridjoko, 2015).
Pesawaran Regency has a potential marine culture area $\pm 3,685$ ha and Lampung Province is one of the grouper production centers that provided 356 tons in 2014 (Datuk, 2016). Based on the study by Kartikasari et al. (2016), the distributions of temperature and $\mathrm{pH}$ in Lampung Bay meet the criteria for the cultivation of groupers according to SNI 6487.4:2011. Seeing this situation, development and improvement of grouper farming in Lampung Bay are necessary. Environmental carrying capacity has a huge effect on the sustainability of grouper farming. Selection of the proper cultivation locations becomes the biggest factor determining the success or failure of grouper culture activities. In addition, grouper farming site selection using appropriate floating net cage is a necessary priority to reduce the occurrence of waters problems such as unconsumed feed or disposal of organic waste from groupers (Palm et al., 2011; Turcios \& Papenbrock, 2014). It is important to pay attention and maintain the condition of water quality around the cages (oxygen and ammonia) and stocking density to prevent groupers from diseases and parasites (Hadiroseyani et al., 2010). Therefore, in this study, analysis of land suitability to determine the location of grouper farming activities in the Lampung Bay was conducted.

\section{MATERIALS DAN METHODS}

\section{Study sites}

The study was conducted in April-May 2012 at 8 am to $5 \mathrm{pm}$ in the general use zone in Lampung Bay, Pesawaran Regency, Lampung (Figure 1). Determination of the observation point was designed using purposive sampling method. Sampling locations as many as 20 stations (Table 1) were expected to represent all waters conditions at the study sites with consideration of 'ecological preference'. Coordinates of sampling were recorded with the help of Global Positioning System (GPS) with the format (latitude; longitude).

\section{Water quality parameters}

Physical, chemical and biological samples were taken at 8:00 am until 17:00 pm. Especially for the dissolved oxygen was taken two times i.e. when there is the sun (09.00 to 16.00 Western Indonesia Time) and after sunset (00.00 to 06.00 Western Indonesia Time). Physical and chemical parameters are environmental parameters measured to determine the location of cultivation. 
Physical parameters measured consisted of water depth, temperature, water transparency, and a load of suspended solids. The depth of the water was measured using bathymeter, temperature using a quality checker (walk lab), water transparency using Secchi disk, a load of suspended solids using a calculation formula refers to the APHA (1992).

Chemical parameters consisting of $\mathrm{pH}$, dissolved oxygen, salinity, nitrate, and phosphate of waters were measured at each sampling point. Measurement of $\mathrm{pH}$ used a $\mathrm{pH}$ meter, dissolved oxygen used a DO meter, and salinity used a refractometer. Measurement of nitrate using a method referred to APHA (1992). Water sample $(10 \mathrm{~mL})$ was filtered using a filter paper, then was added with $0.4 \mathrm{~mL}$ of nitric buffer. After that, reducing agent as much as $0.2 \mathrm{~mL}$ (hydrazine sulfate and cupric sulfate solutions at a ratio of 1:1) was added and the sample was left overnight. Later, it was gradually added with $0.4 \mathrm{~mL}$ acetone, $0.2 \mathrm{~mL}$ sulfanilamide, and $0.2 \mathrm{~mL}$ nepethylenediamine solutions. After 15 minutes, the nitrate concentrations were observed using a spectrophotometer with a wavelength of $543 \mathrm{~nm}$.

Measurement of phosphate was also done using a method referred to APHA (1992). Water sample $(10 \mathrm{~mL})$ was filtered, then put into Erlenmeyer. Each water sample was added with combined reagent $1.6 \mathrm{~mL}$, which consisted of a mixture: $10 \mathrm{~mL} 5 \mathrm{~N} \mathrm{H}_{2} \mathrm{SO}_{4}, 1$ $\mathrm{mL}$ potassium antimonyl tartrate/PAT, $3 \mathrm{~mL}$ ammonium molybdate, and $6 \mathrm{~mL}$ ascorbic acid. After the solution was allowed to stand for 30 minutes, the optical density was observed in the spectrophotometer with a wavelength of 880 $\mathrm{nm}$.

Biological parameters measured in this study were phytoplankton abundance and chlorophyll-a concentration. Samples of phytoplankton and chlorophyll-a which were taken from the field were transported to the laboratory for analysis. Samples of phytoplankton were calculated their abundance using Sedgwick-Rafter counting cell. Meanwhile, the concentration of chlorophyll-a was analyzed by filtering the water sample using $0.45 \mu \mathrm{g} / \mathrm{L}$ millipore and continued the analysis with a spectrophotometric method based on APHA (1992).

\section{Location of assessment for grouper farming using floating net cage systems}

Grouper culture development location with floating net cage systems have criteria grouped into two variables, primary and secondary variables. The primary variables are requirements that must be met in aquaculture development

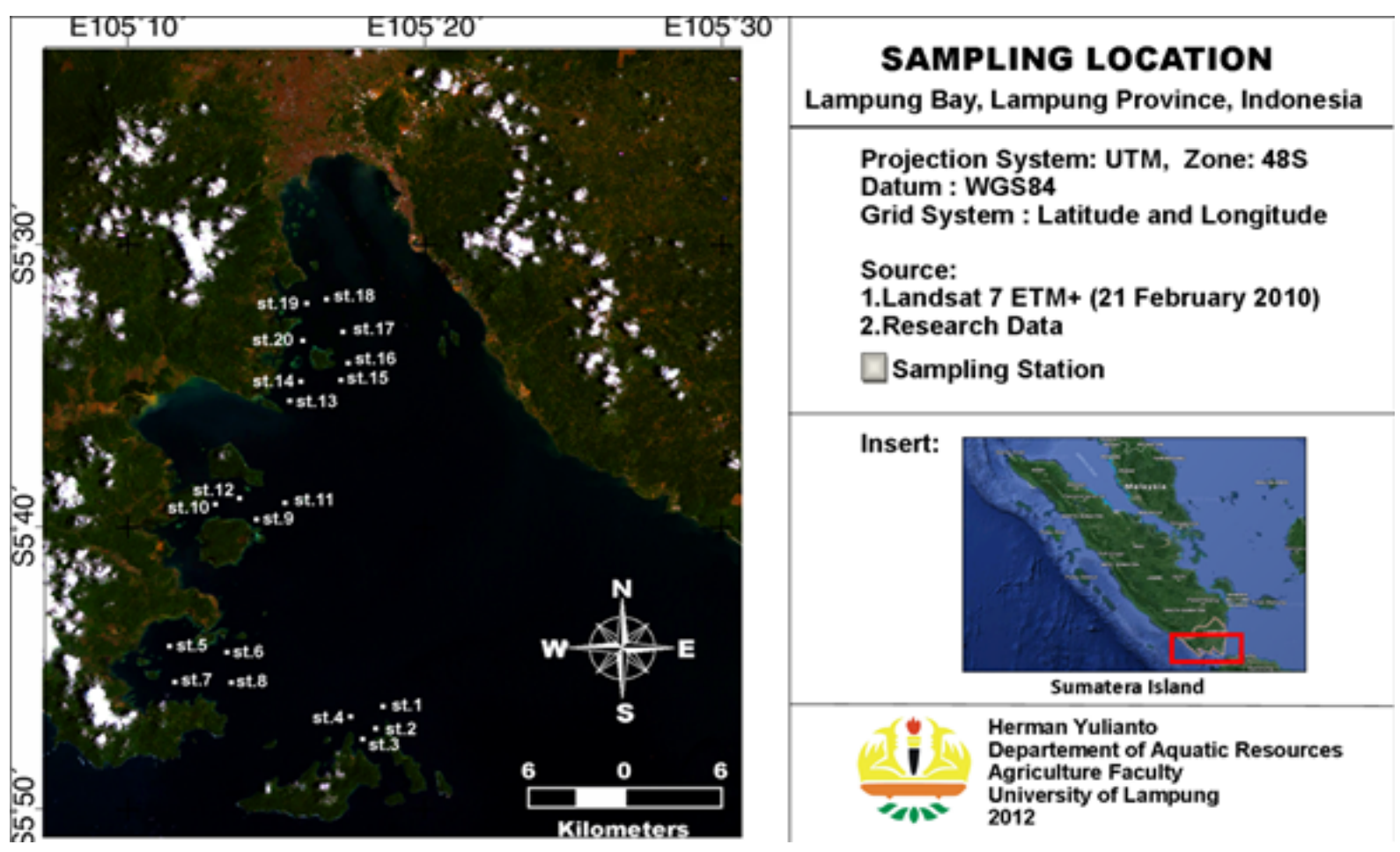

Figure 1. Map of 20 point stations of the study site. 
Table 1. Sampling station

\begin{tabular}{|c|c|c|c|}
\hline \multirow[t]{2}{*}{ No. station } & \multirow[t]{2}{*}{ Name of location } & \multicolumn{2}{|c|}{$\begin{array}{c}\text { Coordinate } \\
(\text { degrees, minutes, seconds) }\end{array}$} \\
\hline & & Latitude & Longitude \\
\hline 1 & Siuncal & $5^{\circ} 46^{\prime} 21.53^{\prime \prime} \mathrm{S}$ & $105^{\circ} 18^{\prime} 35.95^{\prime \prime} \mathrm{E}$ \\
\hline 2 & Siuncal & $5^{\circ} 47^{\prime} 7.62^{\prime \prime} \mathrm{S}$ & $105^{\circ} 18^{\prime} 21.90^{\prime \prime} \mathrm{E}$ \\
\hline 3 & Lesung & $5^{\circ} 47^{\prime} 30.68^{\prime \prime} \mathrm{S}$ & $105^{\circ} 17^{\prime} 55.12^{\prime \prime} \mathrm{E}$ \\
\hline 4 & Legundi & $5^{\circ} 47^{\prime} 1.20^{\prime \prime} \mathrm{S}$ & $105^{\circ} 17^{\prime} 38.04^{\prime \prime} \mathrm{E}$ \\
\hline 5 & Punduh Pidada & $5^{\circ} 44^{\prime} 19.89^{\prime \prime} \mathrm{S}$ & $105^{\circ} 11^{\prime} 33.21^{\prime \prime} \mathrm{E}$ \\
\hline 6 & Tanjung Putus & $5^{\circ} 44^{\prime} 25.93^{\prime \prime} \mathrm{S}$ & $105^{\circ} 13^{\prime} 20.91$ 'Е \\
\hline 7 & Punduh Pidada & $5^{\circ} 45^{\prime} 29.82^{\prime \prime} \mathrm{S}$ & $105^{\circ} 11^{\prime} 35.97^{\prime \prime} \mathrm{E}$ \\
\hline 8 & Punduh Pidada & $5^{\circ} 45^{\prime} 30.53^{\prime \prime} \mathrm{S}$ & $105^{\circ} 13^{\prime} 30.01$ 'E \\
\hline 9 & Puhawang & $5^{\circ} 42^{\prime} 59.50^{\prime \prime} \mathrm{S}$ & $105^{\circ} 13^{\prime} 40.57^{\prime \prime} \mathrm{E}$ \\
\hline 10 & Puhawang & $5^{\circ} 41^{\prime} 38.32^{\prime \prime} \mathrm{S}$ & $105^{\circ} 12^{\prime} 14.48^{\prime \prime} \mathrm{E}$ \\
\hline 11 & Puhawang & $5^{\circ} 41^{\prime} 36.81^{\prime \prime} \mathrm{S}$ & $105^{\circ} 13^{\prime} 38.43^{\prime \prime} \mathrm{E}$ \\
\hline 12 & Puhawang & $5^{\circ} 39^{\prime} 7.89^{\prime \prime} \mathrm{S}$ & $105^{\circ} 15^{\prime} 18.00^{\prime \prime} \mathrm{E}$ \\
\hline 13 & Maitem & $5^{\circ} 35^{\prime} 30.91^{\prime \prime} \mathrm{S}$ & $105^{\circ} 15^{\prime} 27.94^{\prime \prime} \mathrm{E}$ \\
\hline 14 & Maitem & $5^{\circ} 34^{\prime} 50.00^{\prime \prime} \mathrm{S}$ & $105^{\circ} 15^{\prime} 49.95^{\prime \prime} \mathrm{E}$ \\
\hline 15 & Tegal & $5^{\circ} 34^{\prime} 46.96^{\prime \prime} \mathrm{S}$ & $105^{\circ} 17^{\prime} 11.23^{\prime \prime} \mathrm{E}$ \\
\hline 16 & Tegal & $5^{\circ} 34^{\prime} 2.69^{\prime \prime} \mathrm{S}$ & $105^{\circ} 17^{\prime} 23.83^{\prime \prime} \mathrm{E}$ \\
\hline 17 & Tegal & $5^{\circ} 33^{\prime} 5.12^{\prime \prime} \mathrm{S}$ & $105^{\circ} 17^{\prime} 14.39^{\prime \prime} \mathrm{E}$ \\
\hline 18 & Kyoko & $5^{\circ} 31^{\prime} 55.78^{\prime \prime} \mathrm{S}$ & $105^{\circ} 16^{\prime} 41.33^{\prime \prime} \mathrm{E}$ \\
\hline 19 & Teluk Hurun & $5^{\circ} 32^{\prime} 4.11^{\prime \prime} \mathrm{S}$ & $105^{\circ} 16^{\prime} 1.19^{\prime \prime} \mathrm{E}$ \\
\hline 20 & Ringgung & $5^{\circ} 33$ '23.36”S & $105^{\circ} 15^{\prime} 53.399^{\prime \prime}$ \\
\hline
\end{tabular}

efforts, including viability (survival rate) and the sustainability of the business. If this requirement is not met, it will lead to cultivation failure. The primary variables consisted of dissolved oxygen for various metabolic reactions, environmental, and consumptive needs of the fish (Ghufron \& Kordi, 2005). Water flow has a direct impact on the attachment of biofouling on nets and damage to aquaculture installation or even sweeps it away. The grouper fish cultivated in floating net cages releases relatively large amounts of energy to maintain its position against the flow of water that always flows through the net (Paruntu, 2015). Moreover, salinity is also an important variable because it relates to energy use on water salinity. Depth, brightness and the base substrate of waters are also important parameters considering the penetration of light, the fish's ability to take food and fish habits. Grouper will live better in habitats with sandy and muddy substrate and the area around the coral reef ecosystem because it can be used as a shelter and feeding ground (Langkosono, 2007; Mujiyanto \& Syam, 2015).
The secondary variable is also a decisive factor for grouper culture location using floating net cage. Secondary variable included temperature and density of phytoplankton. Phytoplankton density is an important variable as it is an optimal requirement of water fertility.

Primary and secondary data obtained were processed in suitability matrix (Table 2) then produced the score that would be classified into several classes. From the analysis of water suitability, a suitability map will be obtained for grouper culture region using floating net cage with 4 classes: S1 (highly suitable); do not have a limiting factor with a total scoring range of $85-100 \%$, S2 (moderately suitable); do not have a serious margin to implement a given treatment or only a barrier that does not mean to its user and will not raise the level of the input or the treatment given to a total scoring range of $75-85 \%$, S3 (marginally suitable); have a serious barrier to maintain the level of treatment to be applied or barrier will further enhance the level of input or treatment given with a total scoring 
range of $65-75 \%$, and $\mathrm{N}$ (not suitable): can not be used because it has a permanent barrier with a total scoring range of $0-65 \%$ (DKP, 2002).

\section{Data analysis}

The geostatistical model was used as a form of mapping the earth's surface (biotic and abiotic). Data analysis consisted of spatial contour and spatial modeling steps with decreasing of physical, chemical, and biological parameters based on a geo-statistic model. Then conducted the water suitability analysis by making the matrix of conformity. The next step was forming a zone on location with overlay process based on Hartoko (2000). The development of this model was based on Geodetic/position (Degree, Minute, Second/DMS) data transfer to get a single value, with the formula:
Numeric value $($ Lat; Long $)=$

Degree $+\{$ Minute $+($ Second $/ 60)\} / 60$

Data processing to form layers of physical, chemical and biological parameters was performed with Ermapper 7.0 Software.

\section{RESULTS AND DISCUSSION}

Lampung Bay is considered as adequately protected waters. The measurement results of 20 stations showed the range value of each parameter. Physical and chemical parameters of water obtained were water flow at a range of $20.00 \pm 6.89$ $\mathrm{cm} / \mathrm{sec}$, temperature at a range of $29.99 \pm 0.50{ }^{\circ} \mathrm{C}$, clarity at a range of $11.32 \pm 2.92 \mathrm{~m}$, water depth at a range of $26.99 \pm 6.53 \mathrm{~m}$, suspended solids load at a range of $47.05 \pm 18.02 \mathrm{mg} / \mathrm{L}$, dissolved oxygen

Table 2. Assessment system of water suitability for the culture area of grouper

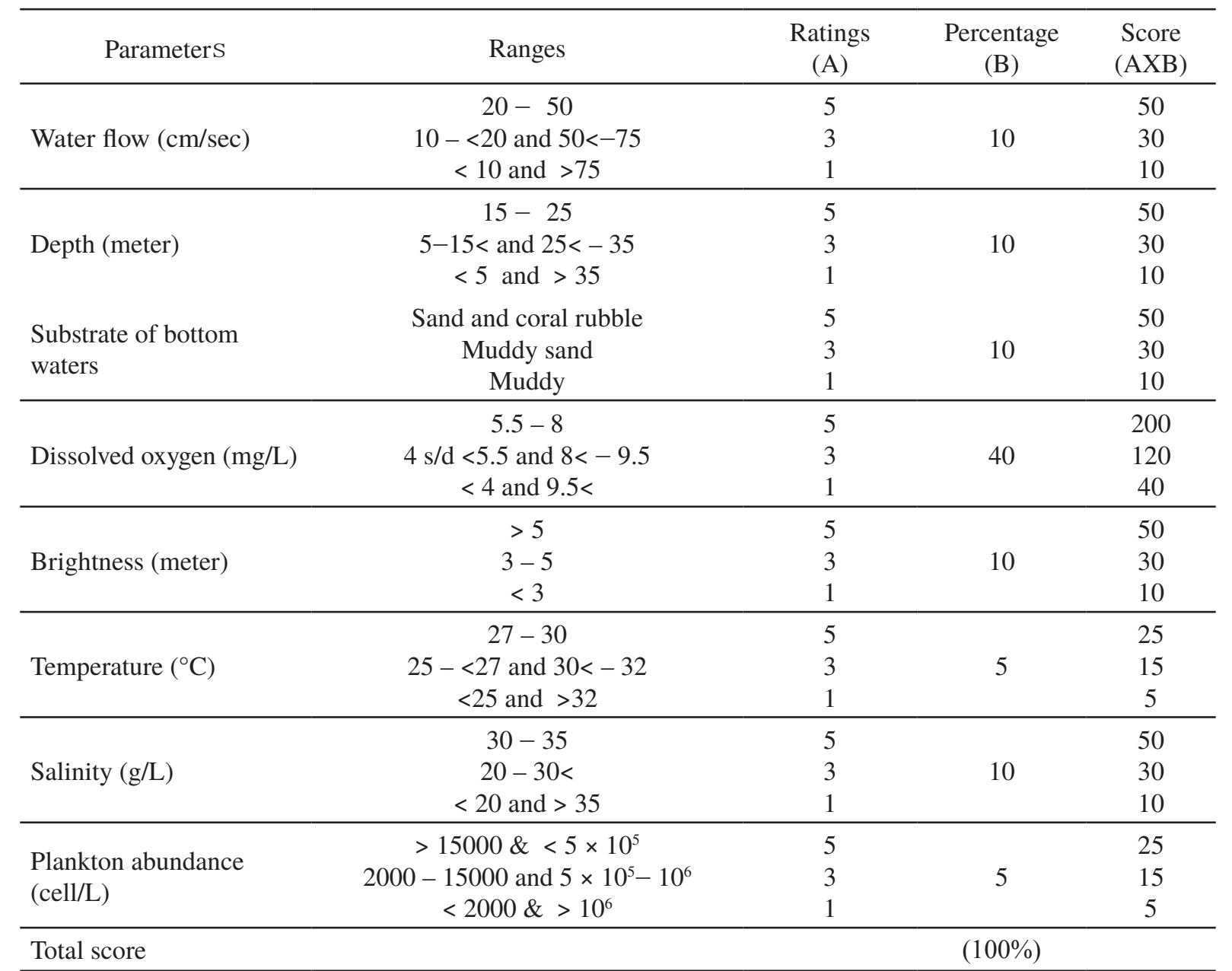

Source: Modification of DKP, 2002; Radiarta et al., 2003; Radiarta et al., 2004; Pramono et al., 2005; Ghufron \& Kordi, 2005; Kangkan et al., 2007; Hartoko et al., 2010; Decree of the Ministry of Environment Number 51 of 2004 on Sea Water Quality Standard.

Note: Score rating (5: good; 3: medium; 1: less) (DKP, 2002). Weight based library/consideration of the influence of the dominant variables. Score is $\sum(\mathrm{n} ; \mathrm{i}=1)=\mathrm{A} \times \mathrm{B}$. 
at a range of $5.22 \pm 0.29 \mathrm{mg} / \mathrm{L}, \mathrm{pH}$ at a range of $8.16 \pm 0.12$, salinity at a value of $33.07 \pm 0.13$ $\mathrm{g} / \mathrm{L}$, nitrate at a range of $0.06 \pm 0.07 \mathrm{mg} / \mathrm{L}$ and phosphate at a range of $0.08 \pm 0.09 \mathrm{mg} / \mathrm{L}$ (Table 3).

Overall measurement of the physical and chemical parameters of water resulted categorized in reasonable value ranges for grouper culture activities using floating net cage. Based on a recent study conducted in Malaysia, the optimum temperature for the cultivation of grouper is 26 and $30^{\circ} \mathrm{C}$ (Moumita De et al., 2016). Putri et al. (2013) state that the growth of groupers will be optimum at a temperature range of $29-31{ }^{\circ} \mathrm{C}$ and salinity of $33 \mathrm{~g} / \mathrm{L}$. That results are same as in the area of Lampung Bay. In addition, Aslianti et al. (2008) also state that the lowest and highest temperature ranges should not be too high, the optimum temperature is only about $1-1.5{ }^{\circ} \mathrm{C}$. Plankton abundance in Lampung Bay has the maximum value. Based on the results of the study by Ismi et al. (2012) groupers were preserved with the addition of Nannochloropsis sp. having a higher survival rate compared to those that were not added with Nannochloropsis sp.

Suspended solids load in Puhawang and Ringgung areas was found to have a high value. This is allegedly due to the high anthropogenic activity around Lampung Bay. Yasrudin (2011) states that the activity of residents around the floating net cage sites can contribute the organic matter into the waters. This has direct implications for the tens of suspended solids load. Water flow in Lampung Bay is suitable for grouper cultivation and obtains a high score of 5 based on the matrix. The water flow condition should be considered as it will affect the availability of dissolved oxygen which is important for the prevention of diseases that often attacked groupers (Dody \& La Rae, 2016).

The scoring result to the suitability of grouper aquaculture in the floating net cage in seven stations (station 1-7) was in the range of 76-80\% (Table 4). This indicated that the stations were classified into the category of moderately suitable (S2). Other 12 stations (station 9-20) obtained a score range of $92-100 \%$ and were categorized into the category of highly suitable (S1). The last station (station 8) achieved the lowest scoring that was $74 \%$ and it was categorized in the category of marginally suitable (S3). Generally, all stations are allowed to conduct grouper culture in the floating net cage.

Based on the scoring results, Lampung Bay waters are suitable to be used as the location for grouper culture in the floating net cage. However, treatments and inputs in some places (station 1-7) to the ecosystem variables had dissolved oxygen concentrations that were below optimum ranges, so those need to be improved. The setting of the water flow is necessary to be considered since it is correlated with dissolved oxygen content. The study conducted by Oedjoe et al. (2012) showed

Table 3. Water quality parameters in Lampung Bay

\begin{tabular}{lcc}
\hline & Parameter & Value \\
\hline Temperature $\left({ }^{\circ} \mathrm{C}\right)$ & & $29.99 \pm 0.50$ \\
& {$[\mathrm{~A}]$} & $5.22 \pm 0.29$ \\
Dissolved oxygen $(\mathrm{mg} / \mathrm{L})$ & $5.63 \pm 0.42$ \\
Salinity $(\mathrm{g} / \mathrm{L})$ & $33.07 \pm 0.13$ \\
$\mathrm{pH}$ & & $8.16 \pm 0.12$ \\
Depth $(\mathrm{m})$ & $26.99 \pm 6.53$ \\
Clarity $($ Secchi depth) $(\mathrm{m})$ & $11.32 \pm 2.92$ \\
Water flow $(\mathrm{cm} / \mathrm{sec})$ & $20.00 \pm 6.89$ \\
Suspended solids load $(\mathrm{mg} / \mathrm{L})$ & $47.05 \pm 18.02$ \\
Nitrate $\left(\mathrm{NO}_{3}\right)(\mathrm{mg} / \mathrm{L})$ & $0.06 \pm 0.07$ \\
Phosphate $(\mathrm{PO})(\mathrm{mg} / \mathrm{L})$ & $0.08 \pm 0.09$ \\
Chlorophyll-a $(\mathrm{mg} / \mathrm{L})$ & $4.37 \pm 1.26$ \\
Plankton abundance $(\mathrm{cells} / \mathrm{L})$ & $89800.17 \pm 12447.56$ \\
Waterbed substrate & Sandy coral \\
\hline
\end{tabular}

Note: [A] Measurement at 00.00 to 06.00 Western Indonesia Time, [B] Measurement at 09.00 to 16.00 Western Indonesia Time 
that the heavy water flow will increase the red blood cells, hematocrit, and hemoglobin levels of tiger grouper juvenile with an optimum water flow rate of $1.25 \mathrm{~m} / \mathrm{sec}$. In order to achieve optimum dissolved oxygen conditions, the farmer needs to pay attention to the stocking density (Santoso, 2007).

In addition, modifications of cage model are needed, especially in places that are far from the settlement like around the Siuncal Island (station $1,2,3$, and 4). This is related to the security and control of the location of a possible disruption due to the high value of grouper commodities (especially the humpback grouper). Groupers have a fairly high price, especially in Hong Kong and other Asian regions with price ranges of US\$ 8-11/kg for gold spot grouper Epinephelus coioides, US\$ $15-20$ for tiger grouper $E$. fuscoguttatus, US\$ 30-40 for coral trout grouper Plectropomus spp. and red grouper E. Akaara, and US\$ 80-95 for humpback grouper Cromileptes altivelis (Williams et al., 2005).

The success of grouper culture activities using floating net cage is highly correlated with accuracy in selecting an appropriate location. The spatial model in Figure 2 on grouper culture zoning in floating net cage showed that all observation stations were categorized into grouper culture zone in the floating net cage. Based on spatial model, the most suitable zone for the cultivation of grouper in the floating net cage was around

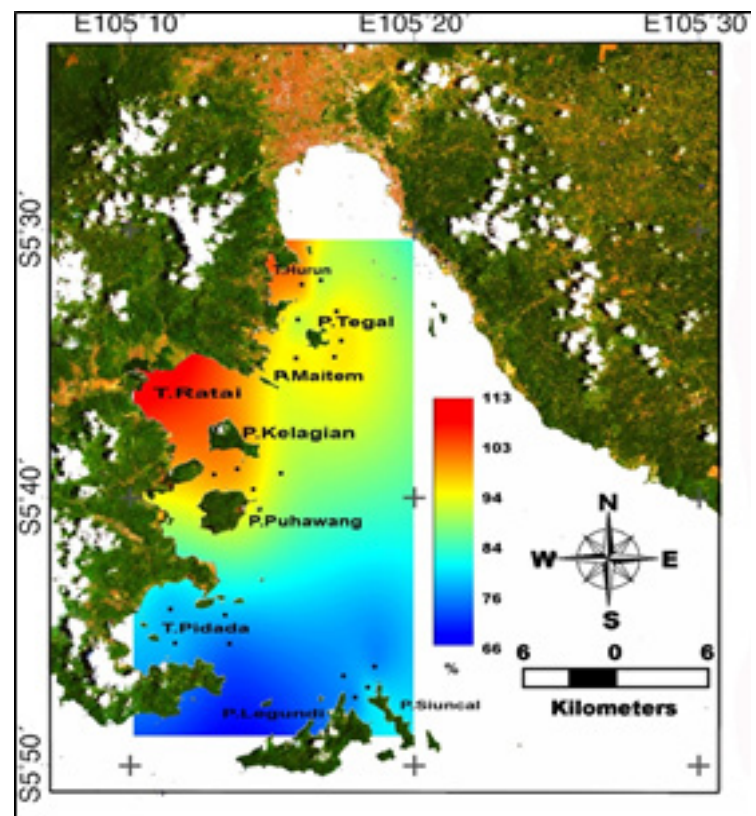

Figure 2. Zoning of water suitability for grouper fish farming. Note: $>85-100 \%$ (S1: highly suitable), $>75-85 \%$ (S2: moderately suitable), >65-75\% (S3: marginally suitable), 0-65\% (N: not suitable).
Puhawang and Kelagian Islands (stations 9, 10, 11, and 12), Maitem Island (stations 13 and 14), Tegal Island (stations 14, 15, 16, and 17), Ringgung (station 20) to Hurun Bay (stations 18 and 19). Until now in those locations, there are grouper culture activities in the floating net cage, especially in the Ringgung area that is also a tourism region and the highest population of grouper culture unit in floating net cage compared to other locations.

The results of the study by Yulianto et al. (2016) also showed that station 9-18 were suitable to be used as pearl oyster Pinctada sp. farming locations, but those locations were not suitable for seaweed (Yulianto et al., 2017) farming locations so that it can be thought more about polyculture design with pearl oyster. Polyculture systems in floating net cage need to be considered to achieve sustainable grouper cultivation activities (Affan, 2012). The rearing of grouper in polyculture system had been studied including the polyculture of grouper with Kappaphycus alvarezii (Radiarta et al., 2014) and also the polyculture of grouper with Trachinotus blochii and Kappaphycus alvarezii (Radiarta \& Erlania, 2016).

Based on geostatistical model conducted on the zoning map for the suitability of grouper culture in the floating net cage (Figure 2), marine areas that can be utilized for grouper culture in the floating net cage are 15,712.6 ha (highly suitable), 13,294.7 ha (moderately suitable), and $4,209.82$ ha (marginally suitable) of the total study area of 33,847.12 ha. This area is larger than in Karimunjawa National Park where the area that is suitable for grouper cultivation is only about 2,107.04 ha with a suitability level of S2 (moderately suitable) (Yusuf, 2013). This suitability site is caused by the presence of Main Centre for Mariculture Development Lampung (BBPBL) located in Hurun Bay. BBPBL can provide grouper fingerlings and can also provide technical guidance for disease treatments to grouper farmers.

\section{CONCLUSION}

Based on spatial analysis results, Lampung Bay is very appropriate for the location of grouper farming. The suitable area for cultivation of grouper in the floating net cages was $33,847.12$ ha with suitability composition levels of including highly suitable (S1) that was $15,712.6$ ha, moderately suitable (S2) that was $13,294.7$ ha and marginally suitable (S3) that was 4,209.82 ha. 
The waters of Lampung Bay that are very suitable for grouper farming zones in the floating net cage are located in the areas around Puhawang Island, Kelagian Island, Maitem Island, Tegal Island to Hurun Bay.

\section{REFERENCES}

Afero F, Safrita AM. 2015. Economic analysis of pond nursery for tiger grouper Epinephelus fuscoguttatus and green grouper Epinephelus coioides in Bireuen District of Aceh Province. Depik 4: 15-23.

Affan JM. 2012. Identification of location for the development of floating net cages based on environmental and water quality factors in east coast Bangka Tengah District. Depik 1: 78-85.

APHA. 1992. Standart methods for the examination of water and wastewater, $16^{\text {th }}$ Edition. Washington DC: American Public Health Association.

Aslianti T, Suwirya K, Asmanik. 2008. Mass culture technology of leopard coral trout Plectropomus leopardus larvae. Jurnal Riset Akuakultur 3: 1-11.

Aslianti T. 2010. Different percentage of water exchange on growth of coral trout grouper fingerling Plectropomus leopardus. Jurnal Ilmu Dan Teknologi Kelautan Tropis 2: 26-33.

Datuk. 2016 June 15-July 14. Kerapu Lampung bisa ekspor lagi. Trobos Aqua. Edition 49 Year $\mathrm{V}: 44$ (column 4).

De M, Ghaffar MA, Bakara Y, Das SK. 2016. Effect of temperature and diet on growth and gastric emptying time ofthe hybrid, Epinephelus Fuscoguttatus $\$ \times$ E. Lanceolatus $0^{\pi}$. Aquaculture Reports 4: 118-124.

Departemen Kelautan dan Perikanan [DKP]. 2002. Modul Sosialisasi dan Orientasi Penataan Ruang, Laut, Pesisir dan Pulau-Pulau Kecil. Jakarta: Ditjen Pesisir dan Pulau-Pulau Kecil, Direktorat Tata Ruang Laut, Pesisir dan Pulau-Pulau Kecil.

Dody S, La Rae D. 2016. Growth rate of humpback grouper Cromileptes altivelis cultured in floating net cages. Oseanologi dan Limnologi di Indonesia 1: 11-17.

Fauzi IA, Mokoginta I, Yaniharto D. 2008. Rearing of humpback grouper Cromileptes altivelis fed on pellet and trash fish in cage culture system. Jurnal Akuakultur Indonesia 7: 65-70.
Ghufron M, Kordi H. 2005. Budidaya Ikan Laut Di Keramba Jaring Apung. Jakarta: Penerbit Rineka Cipta.

Hadiroseyani Y, Effendi I, Rahayu AM, Arianty HS. 2010. Parasites infestation on juvenile tiger grouper Epinephelus fuscoguttatus nursed in net cage at sea farming instalation Kepulauan Seribu, Jakarta. Jurnal Akuakultur Indonesia 9: 140-145.

Harikrishnan R, Balasundaram C, Moon SH. 2010. Molecular studies, disease status and prophylactic measures in grouper aquaculture: economic importance, diseases and immunology. Aquaculture 309: 1-14.

Hartoko A. 2000. Teknologi Pemetaan Dinamis Sumberdaya Ikan Pelagis Melalui Analisis Terpadu Karakter Oseanografi dan Data Satelit NOAA, Landsat_TM dan SeaWIFS_ GSFC di Perairan Laut Indonesian. Kantor Menteri Negara Riset dan Teknologi, Dewan Riset Nasional, Jakarta.

Hartoko A, Kangkan AL. 2010. Spasial modeling for marine culture site selection based on ecosystem parameters at Kupang Bay, East Nusa Tenggara - Indonesia. International Journal of Remote Sensing and Earth Science 6: 57-64.

Hastuty R, Yonvitner, Adrianto L. 2014. Coral cover and composition of reef fishesinside and outsideofmarine protectedareas, eastern coast of Weh Island, Sabang. Depik 3: 99-107.

Imanto PT, Suastika M. 2007. Larval life development of the king grouper E. lanceolatus. Jurnal Ristek Akuakultur 2: 365-372.

Ismi S, Asih YN, Slamet B, Suwirya K. 2012. Optimum density of Nannochloropsis sp. in larval rearing of humpback grouper Cromileptes altivelis. Jurnal Riset Akuakultur 7: 407-419.

Kangkan AL, Hartoko A, Suminto. 2007. Study on site selection for the development of mariculture based on physical, chemical and biological parameters in Kupang Bay, East Nusa Tenggara. Jurnal Pasir Laut 3: 76-93.

Kartikasari F, Jaelani LM, Winarso G. 2016. Analisis sebaran konsentrasi suhu permukaan laut dan $\mathrm{pH}$ untuk pembuatan peta lokasi budidaya kerapu bebek menggunakan citra satelit Landsat-8 (studi kasus: Teluk Lampung, Lampung). Jurnal Teknik ITS 5: A401-A406.

Langkosono. 2007. Budidaya ikan kerapu (Serranidae) pada keramba jaring apung (KJA). Biosfera 24: 90-97.

Luhur ES, Tajerin. 2016. Impacts of export duties 
on its performance of the marine and fisheries sector. Jurnal Sosial Ekonomi Kelautan dan Perikanan 11: 185-200.

Mariskha PR, Abdulgani N. 2012. Aspek reproduksi ikan kerapu macan Epinephelus Sexfaciatus di perairan Glondonggede, Tuban. Jurnal Sains Dan Seni ITS 1: 27-31.

Mujiyanto, Syam AR. 2015. The characteristic habitat of grouper fish in Karimunjawa Islands, Central Java. BAWAL 7: 147-154.

Nuraini S. 2007. Grouper species and lengthweight relationship in Beran Waters, East Kalimantan. Jurnal Iktiologi Indonesia 7: 61-65.

Oedjoe MDR, Suprayitno E, Aulanni'am, Herawati EY. 2012. Effect of flow water velocity on hematology component in improving quality of tiger grouper juvenile Epinephelus Fuscoguttatus. Journal of Coastal Develpopment 15: 260-269.

Palm HW, Kleinertz S, Ruckert S. 2011. Parasite diversity as an indicator of environmental change? an example from tropical grouper Epinephelus Fuscoguttatus mariculture in indonesia. Parasitology 138: 1793-1803.

Paruntu CP. 2015. Mariculture of grouper (Epinephelus tauvina Forsskal, 1775) and rabbit fish (Siganus canaliculatus Park, 1797) in floating net with polyculture system. Jurnal Budidaya Perairan 3:1-10.

Pierre S, Gaillard S, Prevot-D'alvise N, Aubert $\mathrm{J}$, Rostaing-Capaillon O, Leng-Tack D, Grillasca JP. 2008. Grouper aquaculture: asian success and mediterranean trials. Aquatic Conservation: Marine and Freshwater Ecosystems 18: 297-308.

Pierre S, Sandrine G, Nathalie PD, Josiane A, Odile RC, Daniel LT, Joel PG. 2007. Grouper aquaculture: Asian success and Mediterranean trials. Aquatic Conservation: Marine and Freshwater Ecosystems 18: 297-308.

Pramono GH, Hari S, Wiwin A. 2005. Norma, Prosedur, Pedoman, Spesifikasi Dan Standar (NPPSS). Prosedur Dan Spesifikasi Teknis Analisis Kesesuaian Budidaya Kerapu Dalam Keramba Jaring Apung. Bakosurtanal: Pusat Survey Sumberdaya Alam Laut.

Putri DIL, Tumulyadi A, Sukandar. 2013. Tingkah laku pemijahan, pembenihan, pembesaran ikan kerapu tikus Cromileptes altivelis di Balai Budidaya Air Payau Situbondo. PSPK Student Journal 1: 11-15.

Radiarta A, Saputra, Priono B. 2004. Areas suitability mapping for mariculture development in Sateh Bay, West Nusa Tenggara. Jurnal Penelitian Perikanan Indonesia 10: 19-32.

Radiarta IN, Erlania, Sugama K. 2014. Integrated mariculture of seaweed, Kappaphycus alvarezii, and grouper cages in Gerupuk Bay Central Lombok Regency, West Nusa Tenggara. Jurnal Riset Akuakultur 9: 125-134.

Radiarta IN, Erlania. 2016. Performa komoditas budidaya laut pada sistem integrated multitrophic aquaculture (IMTA) di Teluk Gerupuk, Lombok Tengah, Nusa Tenggara Barat. Jurnal Riset Akuakultur 11: 85-97.

Radiarta N, Wardoyo SE, Priono B. Praseno O. 2003. Application of geographic lnformation system (GIS) for site selection of mariculture development in Ekas Bay, West Nusa Tenggara. Jurnal Penelitian Perikanan Indonesia 9: 67-79.

Ruslan, Istikomah. 2009. Pengamatan pembesaran kerapu macan Epinephelus fuscoguttatus pada jaring apung dengan dasar bertingkat. Buletin Teknik Litkayasa Akuakultur 8: 33-36.

Santoso AD. 2007. Study on the optimum stocking rate estimation on tiger grouper Epinephelus fuscoguttatus base on dissolved oxygen budged. Jurnal Riset Akuakultur 2: 341-347.

Sumiono B, Ernawati T, Wedjatmiko. 2010. Analysis of snappers and groupers fisheries in the waters of Barru, South Sulawesi. Jurnal Penelitian Perikanan Indonesia 16: 293-303.

Tridjoko, Haryanti, Muzaki A, Sutarmat T. 2009. Selective breeding of f-2 humpback grouper, Cromileptes altivelis broodstocks. Journal of Fisheries Sciences 11: 138-143.

Turcios A, Papenbrock J. 2014. Sustainable treatment of aquaculture effluents what can we learn from the past for the future? Sustainability 6: 836-856.

Wardana IK, Tridjoko. 2015. Understanding more about the cultured humpback grouper Cromileptes altivelis. Media Akuakultur 10: 23-29.

Williams KC, Smith DM, Williams IH, Irvin SJ, Barclay M. 2005. ACIAR grouper grow-out feeds program and related CSIRO research. Aquaculture Asia Magazine, January-March: 29-33.

Yasrudin S. 2011. Analisis kualitas perairan untuk karamba jaring apung ikan kerapu di Kabupaten Situbondo. Neptunus Jurnal Kelautan 17: 17-26.

Yulianto H, Hartoko A, Anggoro S, Delis PC. 
2016. Suitability analysis of pearl oyster farming in Lampung Bay, Pesawaran, Lampung Province, Indonesia. AACL Bioflux 9: 1208-1219.

Yulianto H, Damai AA, Delis PC, Elisdiana Y. 2017. Spatial analysis to evaluate the suitability of seaweed farming site in Lampung Bay,
Indonesia. Turkish Journal of Fisheries and Aquatic Sciences, Forthcoming 17: 12531261.

Yusuf M. 2013. Analysis of Site Suitability for Sustainable Marine Culture at Karimunjawa National Park. Ilmu kelautan 18: 20-29. 